\title{
Energy Yield and Economic Analysis of Tracker Controlled and Fixed Angle Photovoltaic Solar Power System
}

\author{
Imran Ali Shah, Waqas Khalid, Tallal Ahmed*, Qurat-ul-Ain Mehfooz, Narmeen Irshad \\ Alternate Energy Research \& Innovation Lab, University of Engineering \& Technology (UET), Lahore, Pakistan
}

Copyright $(2017$ by authors, all rights reserved. Authors agree that this article remains permanently open access under the terms of the Creative Commons Attribution License 4.0 International License

\begin{abstract}
The efficiency of the solar system is affected by the angle between a photovoltaic (PV) panel and sun. More direct sun light on PV modules leads to enhanced energy yield. Therefore, tracking systems are implemented to improve the performance of PV system by tracking sun trajectory. With the advent of different applications of PV solar power, system planners have been implementing different strategies and techniques to maximize the output of solar system with commonly available technology in market. The foremost purpose of this study was to provide comparison of energy yield for timer based tracker controlled PV system and fixed angle PV system. Furthermore, implementation cost and payback analysis for both types of systems have also been done. This study is performed to find the feasibility of tracker system installation based on energy generation over sizable period of time. The base line results of this study were obtained via software based simulation techniques as well as physical implementation of simulated system to analyze the various parameters. Various simulation software (mainly PVsyst and Meteonorm) are used. Tracker based PV system and fixed angle PV system were designed and simulated via PVsyst 5.61 software. Both the simulated systems were practically installed and analyzed in real time conditions. Additionally, various mathematical techniques were utilized to analyze the results gathered from simulations and physical implementation. Results of this study are based on two types of analysis. First, comparison of simulated with real time measured values for the systems. Secondly, cost benefit analysis of both technologies is done in terms of payback period. This work differs from the rest as both PV systems were simulated and practically implemented to get appropriate results and mainly all the equipment and services utilized in installation are widely available in local market. As tracker based PV systems seem less viable in market due to the recent cost reduction of PV modules, so in this study the feasibility of tracker based PV systems is analyzed.
\end{abstract}

Keywords PV (Photovoltaic), PVsyst, Meteonorm, Single Axis Tracker, RTC (Real Time Clock), Energy Yield

\section{Introduction}

Excessive demand of electrical energy is leading towards usage of diverse power sources in modern power system. The research has been going on to develop efficient means for power systems to perform better [1-3]. Development of sun tracking system is also part of that research race which is used to harness more power from solar panels by directing solar panels to sun light. Different techniques have been developed for solar tracking system. Timer based solar tracking automatically adjust the solar panel at more optimum position based on time with the help of servo motor connected to solar panel [4]. An algorithm developed by interfacing external RTC with microcontroller to control the position of PV modules using linear actuators. In this method, a relationship is developed between time and sun position with experiments in day time. Besides, another important factor analyzed in this study, is cost analysis of fixed angle vs tracker based solar power system (SPS). It is quite obvious that the tracker based SPS cost more than the fixed angle but the main ambiguity lies in the question that: Does the increased energy yield pays back the tracker system price or not? If it does pay back, then is it beneficial to install the tracker systems or not? To get an answer, two both the solar systems were simulated and physical installed keeping all the parameters mainly inverter and PV modules identical. The data of physically installed system were recorded for a complete year and compared the final results with the software simulated models. The savings due to increased energy yield of tracker controlled SPS were also considered and compared with the capital cost of tracker. This paper is further divided in Sections 2, 3, 4 and 5. Section 2 explains 
the methodology, Energy Yield Analysis is described in section 3, detailed cost analysis and cash flow study is described in chapter 4 of the paper whereas Section 5 concludes with financial feasibility and impacts, as well as unique outcomes regarding performance of two types of systems.

\section{Methodology}

Actuators are required to move solar trackers on a certain axis either its dual or single, in this study it is single axis tracker with tilt limits of $-65^{\circ}$ to $65^{\circ}$. Linear actuators are required for any of the system type mentioned above and controllers are designed to control these actuators. Two major methods are utilized for the controller systems, on is the optical sensor system (LDR) which tracks the trajectory of sun and moves the tracker accordingly [5-8]. The other one is based on mathematical calculation and based on time data provided by RTC [9-12]. The former one has some issues like in cloudy days the tracker starts pointing in wrong directions and beside this the optical sensors are also need cleaning due to dust accumulation. A microcontroller with an external RTC is employed in this study. Fig. 1. shows the block diagram defining key components of the tracker system controller.

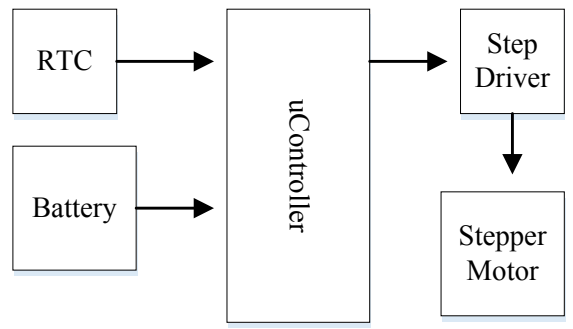

Figure 1. Block diagram of tracker controller
Fig. 2. explains the algorithm for the RTC based tracker controller used in this project.

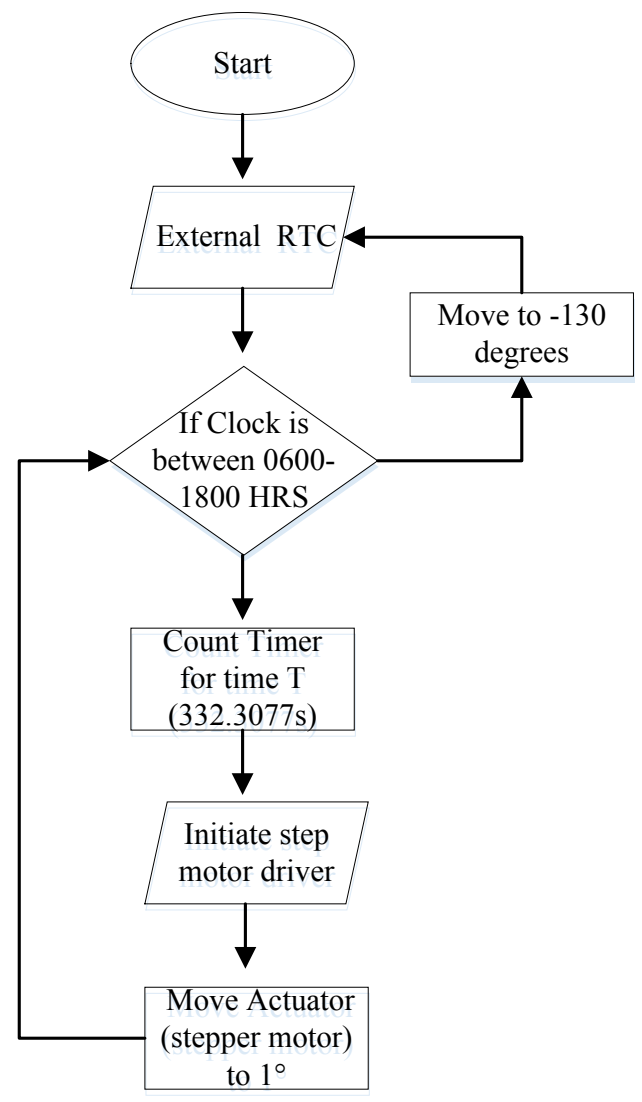

Figure 2. Algorithm of timer based tracker controller

Fig. 3. shows the flow diagram which explains the project flow. Although it cannot cover the whole scheme of current study but somehow explains that how the energy yield analysis of both the systems is performed. 


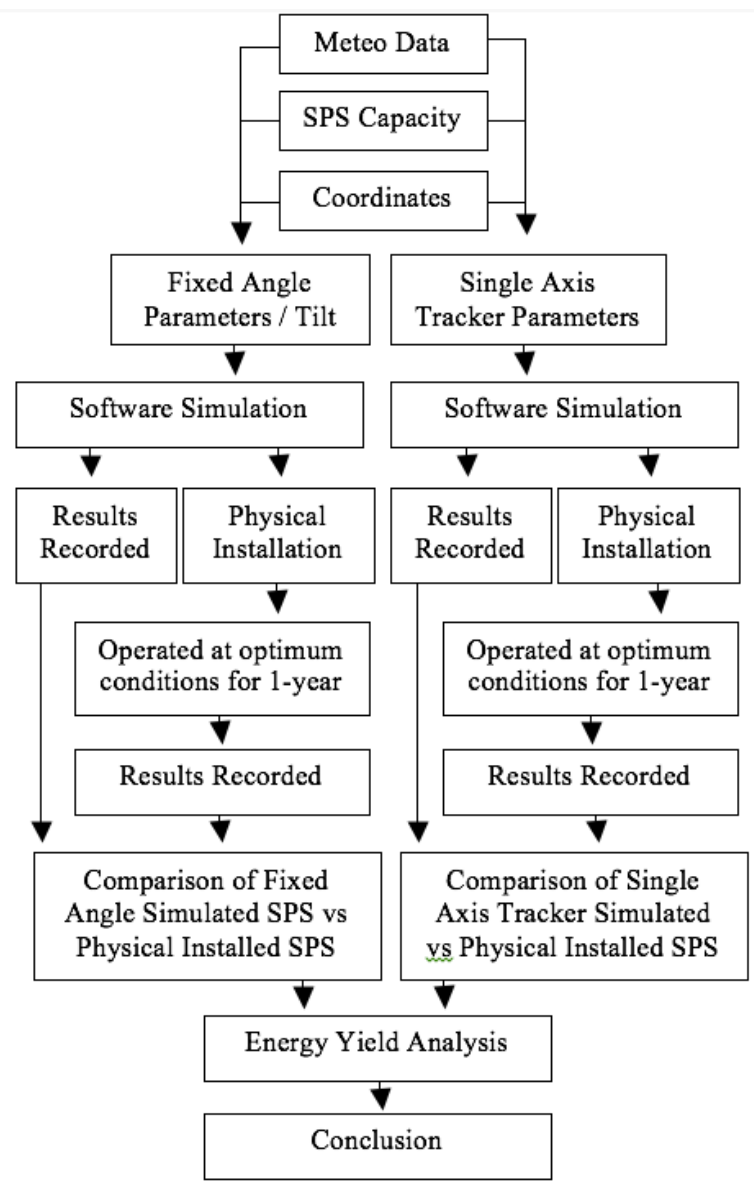

Figure 3. Flow diagram of analysis

The tracker is capable of total $130^{\circ}$ rotations in 12 hours. The hours are 06:00-18:00 i-e hours of solar availability. $130^{\circ}$ rotations are selected as current tracker design allows the tracker to move between $-65^{\circ}$ to $65^{\circ}$. The controller keeps checking RTC that either it's the time of solar availability or not, if the controller finds that it's the time of solar availability than it starts to count the time and when the time is sufficient enough to rotate the tracker to $1^{\circ} \mathrm{i}$-e $332.3077 \mathrm{sec}$ it initializes the stepper motor driver and ultimately the actuator moves the tracker $1^{\circ} .332 .3077 \mathrm{sec}$ which equals $5.538 \mathrm{~min}$ is the time in which the tracker must be moved $1^{\circ}$ in order to track maximum solar energy. Mathematical calculation is performed by taking in view the bounded trajectory of tracker and its movement against sun to achieve maximum solar energy which will fall on solar modules. This controller keeps checking this condition until it the times comes when the sun is no more shining over the modules. In this condition, the controller checks again initialize the step driver and move the tracker system to initial state where it should be at 06:00 in the morning and in this way this cycle continues. This tracker system eliminated the issues related to optical sensors and also the maintenance and cleaning of optical sensors.

\subsection{SPS Capacity (Solar Power System)}

A $2.0 \mathrm{kWp}$ solar system consisting of 8 photovoltaic modules each $250 \mathrm{Wp}$ manufactured by Q-Cells was selected for the project. A $2.0 \mathrm{~kW}$ inverter (SMA Sunny Boy-2000-HF-30) was selected and system was designed in grid-tied mode with configuration to feed all the energy to grid. Two systems were selected with same components, however, with different tracking systems: one with fixed angle mounting structure and the other mounting structure capable of single axis sun tracking allowing PV modules to absorb all the energy that is being wasted in fixed angle system [13].

\subsection{Software Simulation}

PVsyst 5.61 is used to simulate both fixed angle and single axis tracker controlled SPS in grid-connected configuration. Firstly, the system was simulated with fixed multiple angles and best angle was selected, then the same system was simulated with single axis tracker with multiple tracker options. The E-W scheme was adopted for maximum energy yield. The PVsyst simulates the system for complete year with different energy yields of different months while the irradiance is measured and averaged over an hour. Monthly and annual data is recorded and analyzed so that it could be compared in future with physical implementation.

\subsection{Physical Installation}

The two software simulated system designs were physically installed, SPS with fixed angle mounting structure (Fig. 4) and SPS with E-W single axis tracker system (Fig. 5 and Fig. 6). Both systems were installed in grid tied mode and all the generated energy was fed to grid via an energy meter and all the energy was recorded. As the system was located in the industrial estate, there is no load shedding in day time with very low grid failures. Both the systems were installed nearby at distance of approx. 15 meters, operated and maintained at same physical conditions. The energy data from both the systems was regularly recorded for complete year so that it can be compared with each other and also with software results.

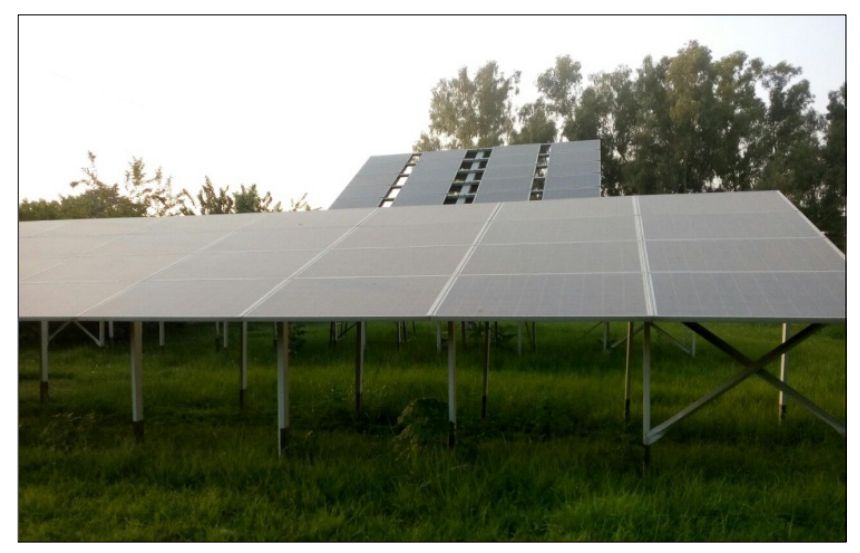

Figure 4. SPS with fixed angle mounting structure

The fixed angle system was installed with fixed tilt angle 
$32^{\circ}$ as shown in Fig. 4. This system was grid-connected and all the generated energy was fed to the grid and recorded [14].

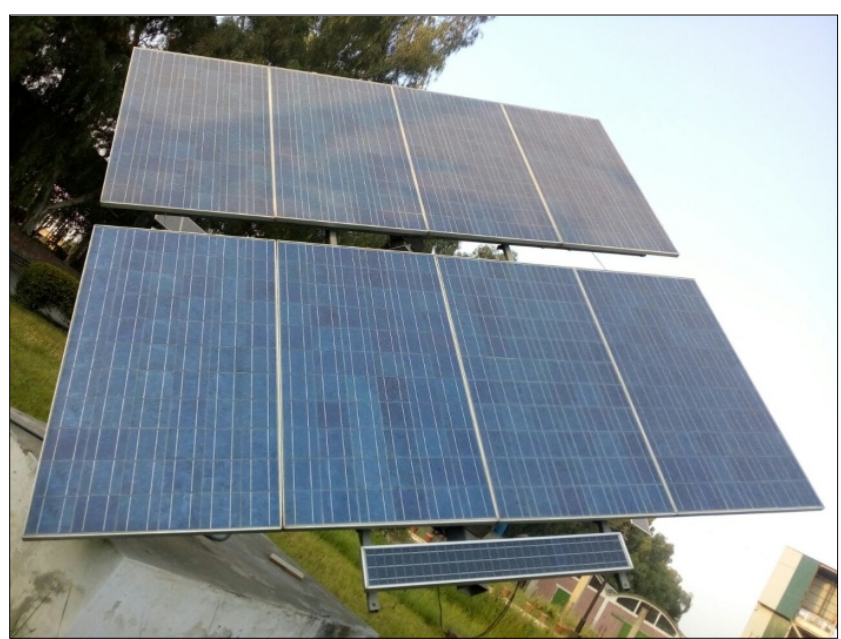

Figure 5. SPS with E-W single axis solar tracker

Other system installed with single axis sun tracker with minimum tilt of $-65^{\circ}$ and maximum tilt of $65^{\circ}$. This system was also fully grid-connected and energy metering was done to record and analyze the energy yield.

Although dual axis system is more efficient than single axis system [15] but in this study, timer based actuator control mechanism was installed for single axis tracker as shown in Fig. 6. The energy meter can also be seen in the same figure.

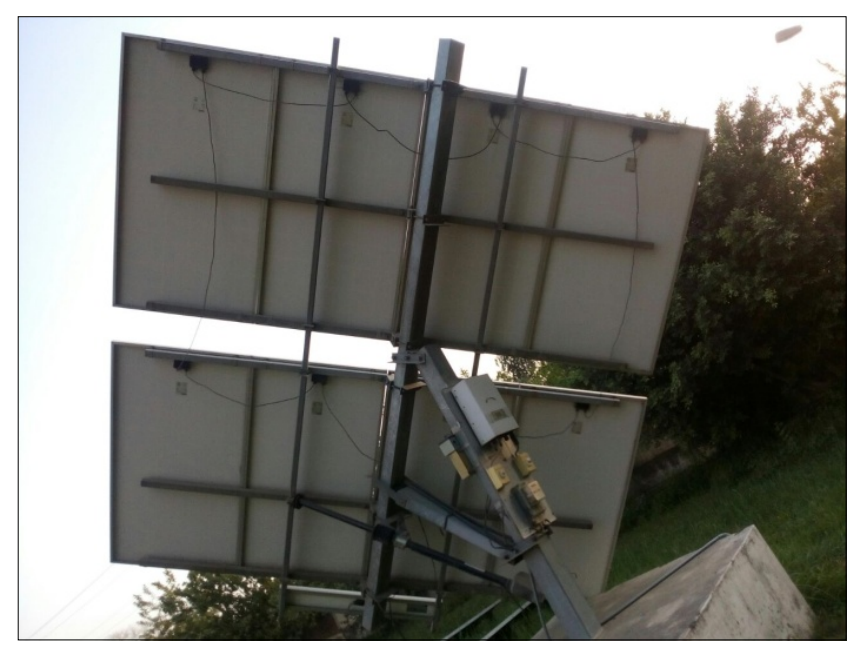

Figure 6. SPS with E-W single axis solar tracker

\subsection{Site Meteo \& Coordinates}

The actual site of systems installation is located in Hattar. Hattar (Urdu: حطار) is one of the 44 union councils, administrative subdivisions, of Haripur District in the Khyber Pakhtunkhwa province of Pakistan [1]. It is located south of the district capital, Haripur, at $33^{\circ} 51^{\prime} 1 \mathrm{~N} 72^{\circ} 51^{\prime} 8 \mathrm{E}$ and borders Taxila Tehsil of Punjab province, Pakistan.

Fig. 7 shows daily average sun hours of each month, which were taken into account for calculations. The maximum of $9.9 \mathrm{Hrs}$ are recorded in month of May and the lowest 7.1 Hrs were recorded in month of January [16].

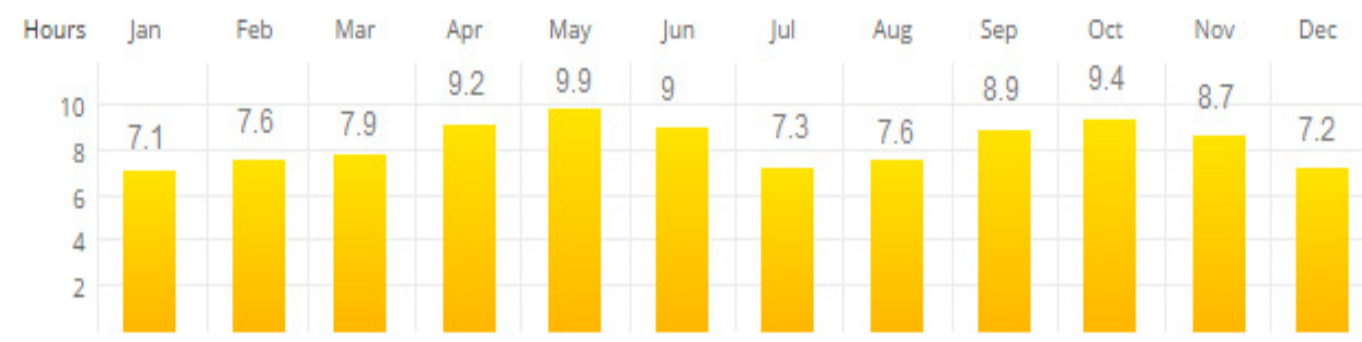

Figure 7. Monthly solar hour data of site

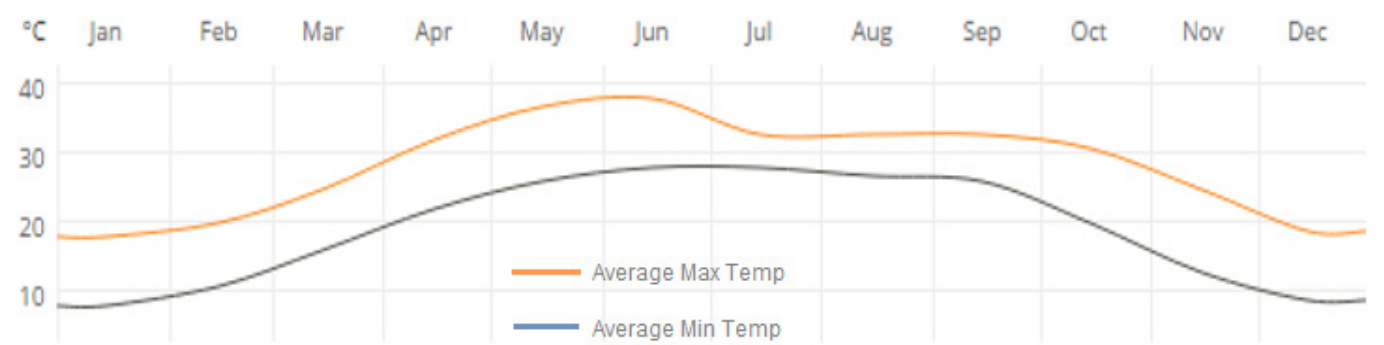

Figure 8. Temperature variations of site 
Besides the peak solar hours, another factor that must be considered in solar power generation is the temperature intensity [17]. Fig. 8 shows the temperature variations during different months of the year.

The array voltage sizing is shown in Fig. 9. shows that the voltage \& current of PV array is within mpp (maximum power point) of inverter.

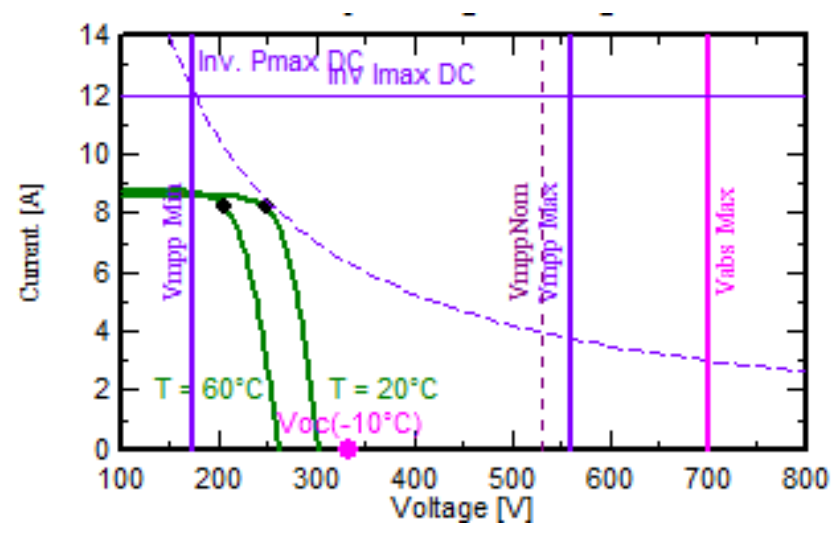

Figure 9. Array voltage sizing

\section{Energy Yield Analysis}

\subsection{Energy Generation of Fixed Angle SPS}

Energy generation was analyzed for both the simulated and physically installed fixed angle SPS. The simulation parameters for fixed angle SPS are shown in Fig. 10. The simulated energy generation of fixed angle SPS is stated in Fig. 13. It is obvious that all the energy generated couldn't fed into grid due to various losses, as shown in Fig. 11.

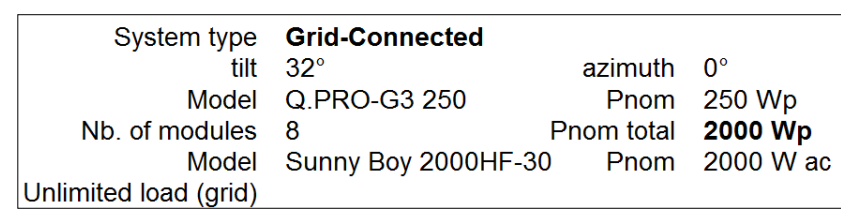

Figure 10. Simulation parameter of Fixed Angle SPS

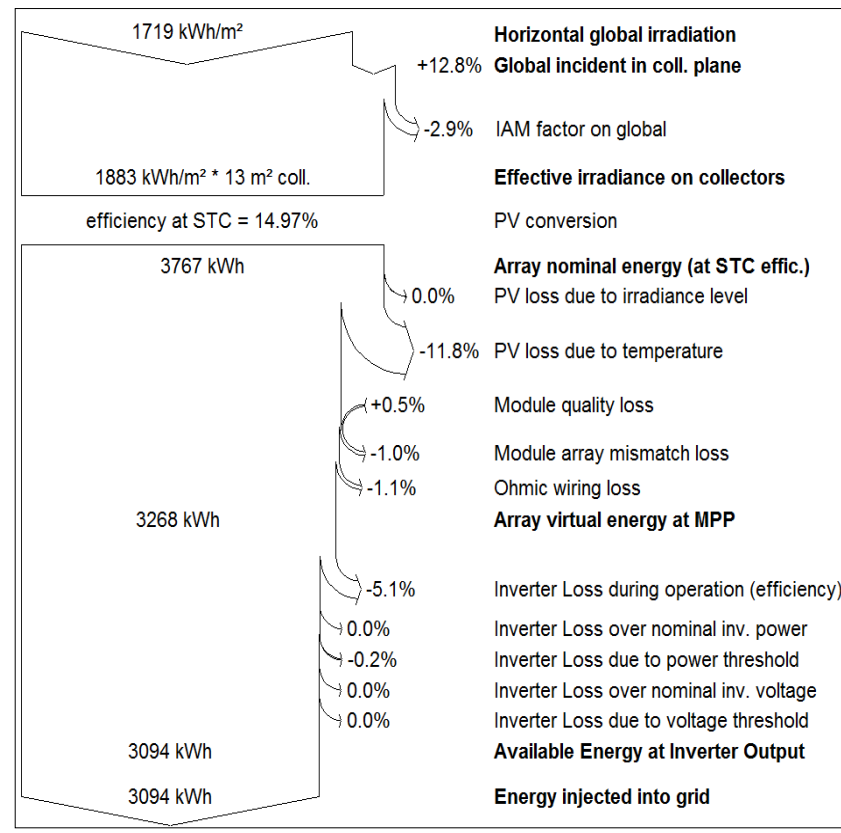

Figure 11. Loss diagram over the whole year

The monthly energy that is expected (software simulation) to fed into grid is listed in Fig. 13, this expected energy generation was compared with the energy generations of physically installed system and actual generation was compared with the generation of tracker based system, all the variables like string tempter loss, ohmic loss due to cables, connection \& joints loss etc. are considered in simulations. 


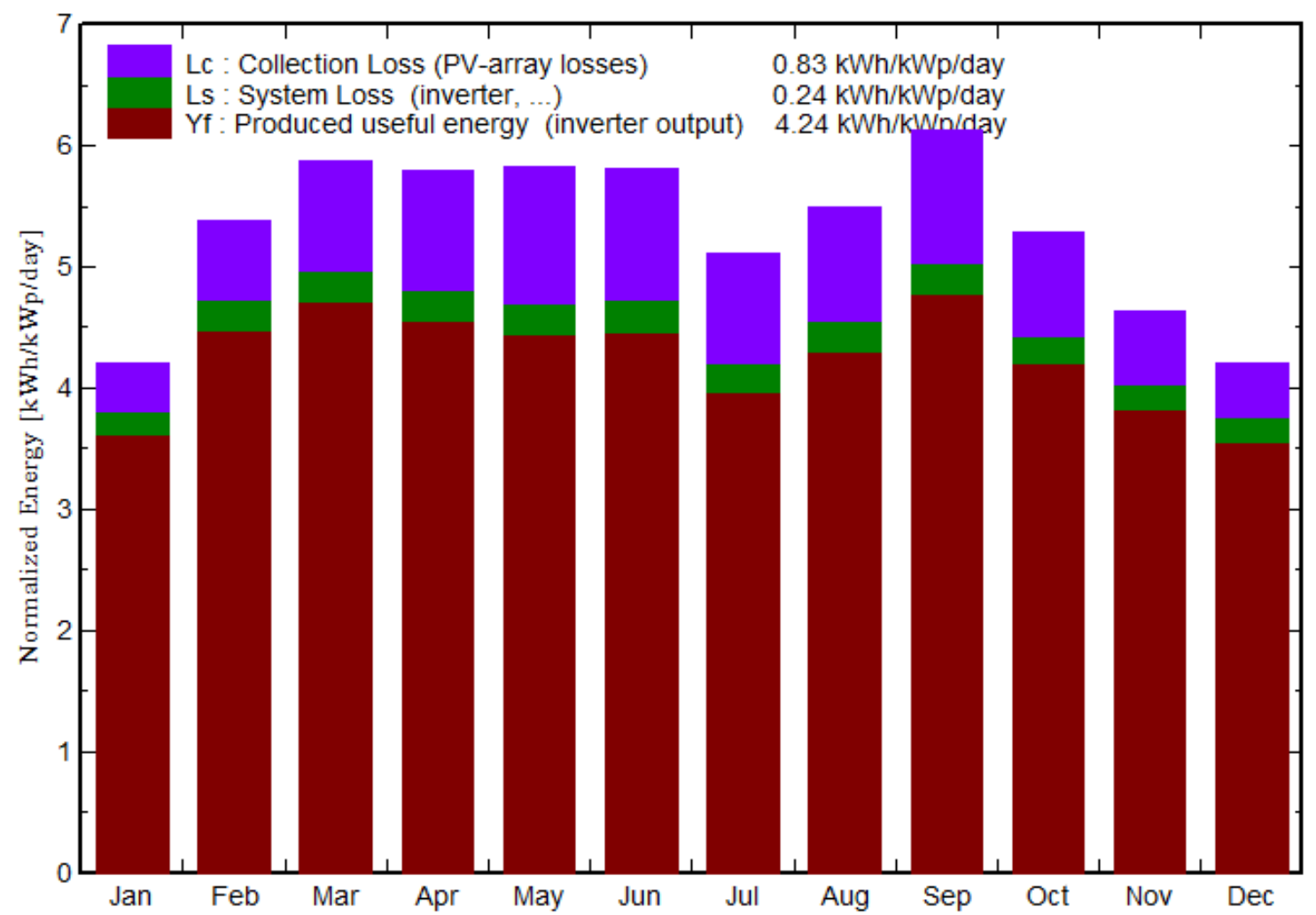

Figure 12. Normalized Production (per installed KWp)

\begin{tabular}{|l|c|c|c|c|c|}
\hline & $\begin{array}{c}\text { GlobHor } \\
\mathrm{kWh} / \mathrm{m}^{2}\end{array}$ & $\begin{array}{c}\text { Globlnc } \\
\mathrm{kWh} / \mathrm{m}^{2}\end{array}$ & $\begin{array}{c}\text { GlobEff } \\
\mathrm{kWh} / \mathrm{m}^{2}\end{array}$ & $\begin{array}{c}\text { EArray } \\
\mathrm{kWh}\end{array}$ & $\begin{array}{c}\text { E_Grid } \\
\mathrm{kWh}\end{array}$ \\
\hline January & 89.2 & 130.3 & 126.8 & 236.1 & 224.4 \\
February & 110.9 & 150.8 & 147.3 & 264.5 & 250.7 \\
March & 153.3 & 182.3 & 177.6 & 308.2 & 292.3 \\
April & 167.0 & 173.7 & 168.4 & 288.3 & 273.1 \\
May & 189.5 & 180.7 & 174.8 & 291.7 & 275.6 \\
June & 190.2 & 174.5 & 168.7 & 283.8 & 267.7 \\
July & 170.7 & 158.5 & 153.1 & 260.9 & 246.0 \\
August & 171.7 & 170.4 & 165.0 & 282.1 & 267.0 \\
September & 163.4 & 184.1 & 179.1 & 302.4 & 286.5 \\
October & 130.1 & 163.9 & 159.6 & 274.7 & 260.7 \\
November & 97.1 & 138.8 & 135.3 & 242.0 & 229.4 \\
December & 86.1 & 130.5 & 127.4 & 233.2 & 220.6 \\
\hline Year & 1719.2 & 1938.5 & 1883.1 & 3267.9 & 3094.0 \\
\hline
\end{tabular}

Figure 13. Simulated energy generation of fixed angle SPS 
Table 1. Actual Energy Generation of Fixed Angle SPS (Physical Installation)

\begin{tabular}{|c|c|}
\hline Month & Energy $(\mathrm{kWh})$ \\
\hline January & 228.62 \\
\hline February & 259.36 \\
\hline March & 276.68 \\
\hline April & 253.32 \\
\hline May & 255.95 \\
\hline Jun & 248.93 \\
\hline July & 225.53 \\
\hline August & 247.99 \\
\hline September & 256.87 \\
\hline October & 241.96 \\
\hline November & 217.47 \\
\hline December & 204.80 \\
\hline Total(Year) & 2917.46 \\
\hline
\end{tabular}

\subsection{Energy Generation of Tracker Controlled SPS}

Similar to the fixed angle PV system, both the simulated and actual energy generation of the tracker controlled PV system was recorded and analyzed. Fig. 14 shows the simulation parameters of the tracker controlled SPS.

\begin{tabular}{|rlrl|}
\hline System type & Grid-Connected & \\
Normal azimut to axis & Normal azimut to axis & $0^{\circ}$ \\
Model & Q.PRO-G3 250 & Pnom & $250 \mathbf{W p}$ \\
Nb. of modules & 8 & Pnom total & $2000 \mathbf{~ W p}$ \\
Model & Sunny Boy $2000 \mathrm{HF}-30$ & Pnom & $2000 \mathrm{~W}$ ac \\
Unlimited load (grid) & & & \\
\hline
\end{tabular}

Figure 14. Simulation parameters for tracker controlled SPS
The power loss diagram for tracker controlled SPS is shown in Fig. 15. The irradiance and corresponding normalized array and system production is shown in Fig. 16 and normalized production (per KWp) stating useful energy developed for output is mentioned in Fig. 17.

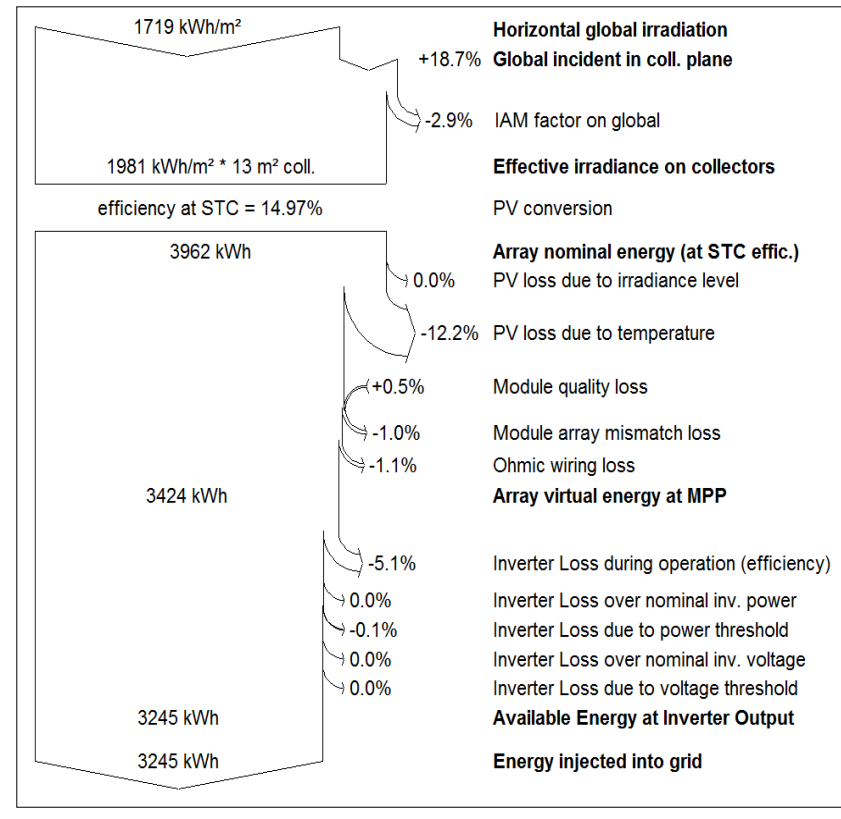

Figure 15. Loss diagram over the whole year (Tracker Controlled SPS)

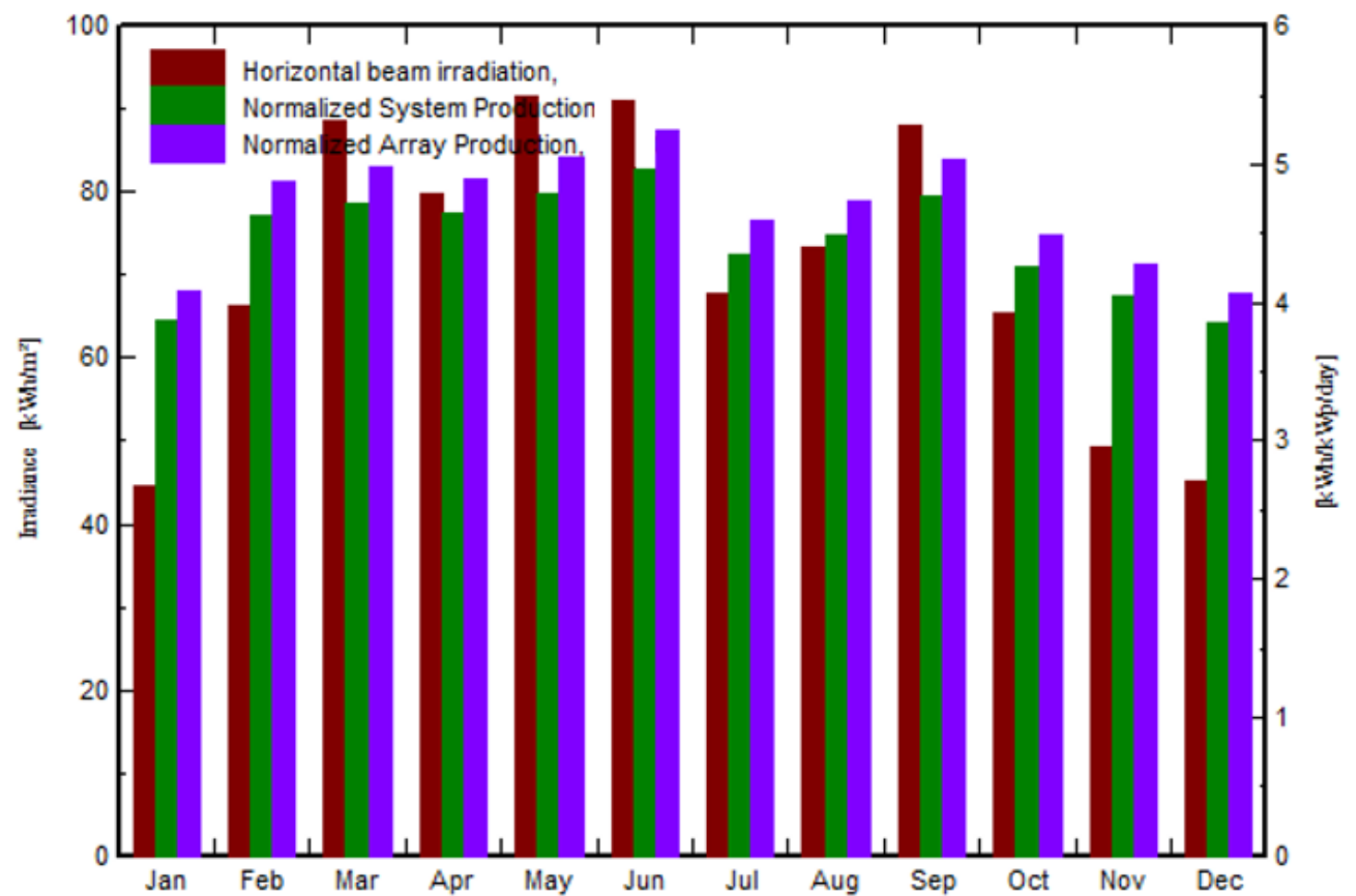

Figure 16. Irradiance Chart 


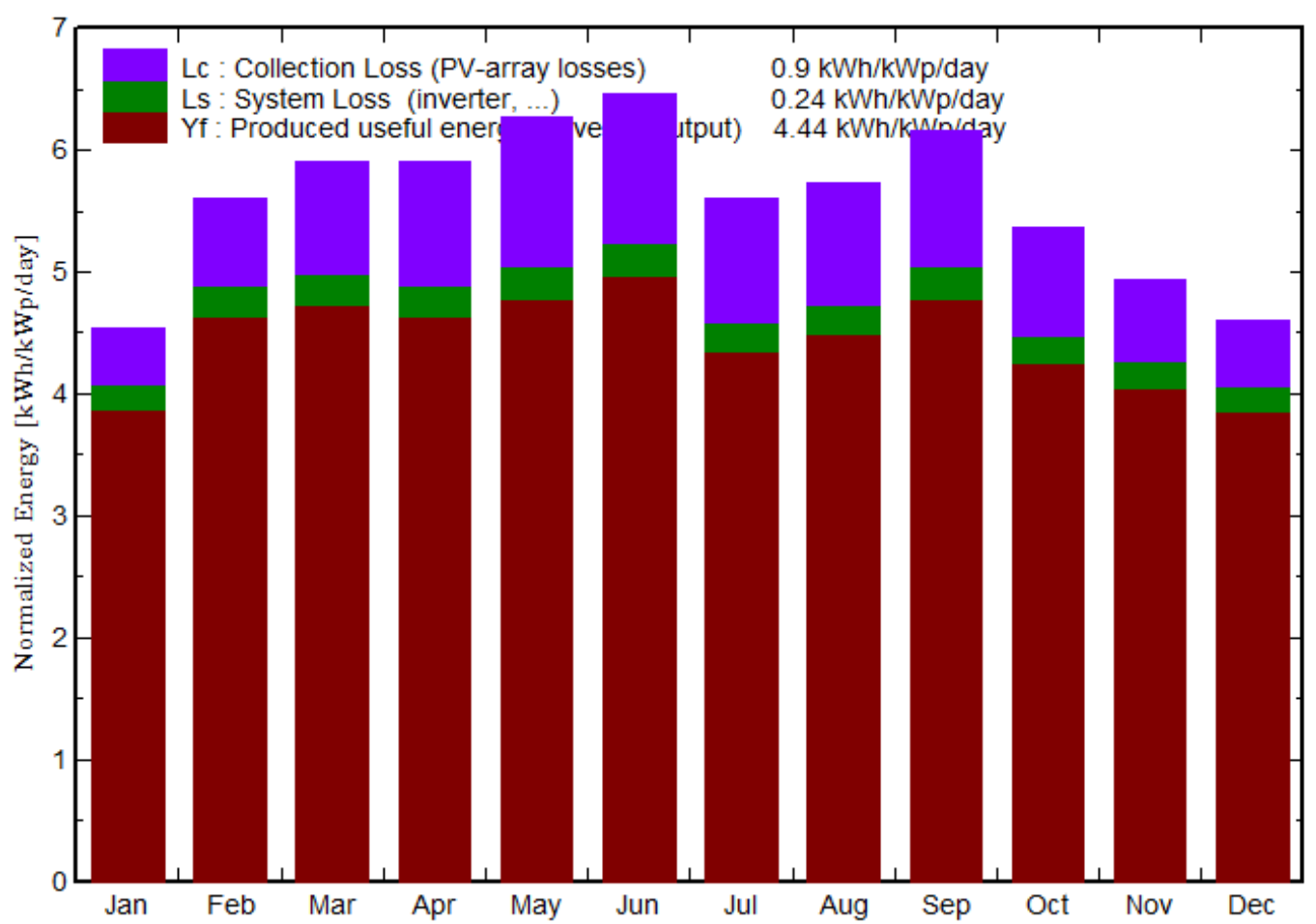

Figure 17. Normalized Production (per installed KWp)

\begin{tabular}{|l|c|c|c|c|c|}
\hline & $\begin{array}{c}\text { GlobHor } \\
\mathrm{kWh} / \mathrm{m}^{2}\end{array}$ & $\begin{array}{c}\text { Globlnc } \\
\mathrm{kWh} / \mathrm{m}^{2}\end{array}$ & $\begin{array}{c}\text { GlobEff } \\
\mathrm{kWh} / \mathrm{m}^{2}\end{array}$ & $\begin{array}{c}\text { EArray } \\
\mathrm{kWh}\end{array}$ & $\begin{array}{c}\text { E_Grid } \\
\mathrm{kWh}\end{array}$ \\
\hline January & 89.2 & 140.6 & 137.3 & 252.8 & 240.2 \\
February & 110.9 & 156.8 & 153.2 & 273.5 & 259.4 \\
March & 153.3 & 183.3 & 178.1 & 309.0 & 292.9 \\
April & 167.0 & 177.4 & 171.4 & 293.6 & 278.4 \\
May & 189.5 & 194.3 & 187.9 & 313.0 & 296.5 \\
June & 190.2 & 193.9 & 187.7 & 314.6 & 297.8 \\
July & 170.7 & 173.6 & 167.5 & 284.7 & 269.3 \\
August & 171.7 & 177.8 & 171.6 & 293.4 & 278.1 \\
September & 163.4 & 184.7 & 179.1 & 302.6 & 286.7 \\
October & 130.1 & 166.5 & 161.9 & 277.9 & 263.7 \\
November & 97.1 & 148.3 & 144.8 & 256.3 & 242.9 \\
December & 86.1 & 142.9 & 140.0 & 252.2 & 238.8 \\
\hline Year & 1719.2 & 2040.2 & 1980.5 & 3423.6 & 3244.8 \\
\hline
\end{tabular}

Figure 18. Simulated energy generation of single axis tracker controlled SPS

It can be clearly seen that the expected energy generation of fixed angle SPS (Fig. 13) is less as compared to the tracker controlled SPS (Fig. 18). The detailed analysis of energy yield is listed in section 3.3. Furthermore, EArray (energy generated by photovoltaic modules) is greater than the EGrid (energy fed into the grid) in both the cases because of power losses in inversion and other factors explained in power flow diagrams (Fig. 11 and Fig. 15). The difference among the expected yields and actual yields was also analyzed and enlisted in 3.3 section.

\subsection{Comparison between Energy Yields}

Detailed analysis was performed among expected and actual energy yields of both systems, and results were recorded which are stated in Table 3, 4. 
Table 2. Actual Energy Generation of Single Axis Tracker Controlled SPS (Physical Installation)

\begin{tabular}{|c|c|}
\hline Month & Energy $(\mathrm{kWh})$ \\
\hline January & 251.96 \\
\hline February & 269.87 \\
\hline March & 289.69 \\
\hline April & 266.40 \\
\hline May & 287.25 \\
\hline Jun & 279.24 \\
\hline July & 253.89 \\
\hline August & 259.20 \\
\hline September & 269.95 \\
\hline October & 256.92 \\
\hline November & 232.40 \\
\hline December & 220.30 \\
\hline Total (Year) & 3137.07 \\
\hline
\end{tabular}

Table 3. Comparison between Expected and Actual Energy Yields of Fixed Angle SPS

\begin{tabular}{|c|c|c|}
\hline Month & $\begin{array}{c}\text { Expected Energy (Fixed Angle) } \\
(\mathrm{kWh})\end{array}$ & $\begin{array}{c}\text { Actual Energy (Fixed Angle) } \\
(\mathrm{kWh})\end{array}$ \\
\hline Jan & 224.4 & 228.62 \\
\hline Feb & 250.7 & 259.36 \\
\hline Mar & 292.3 & 276.68 \\
\hline Apr & 273.1 & 253.32 \\
\hline May & 275.6 & 255.95 \\
\hline Jun & 267.7 & 248.93 \\
\hline Jul & 246 & 225.53 \\
\hline Aug & 267 & 247.99 \\
\hline Sep & 286.5 & 256.87 \\
\hline Oct & 260.7 & 241.96 \\
\hline Nov & 229.4 & 217.47 \\
\hline Dec & 220.6 & 204.80 \\
\hline Total & 3094.00 & 2917.46 \\
\hline
\end{tabular}

Table 4. Comparison between Expected and Actual Energy Yields of Tracker Controlled SPS

\begin{tabular}{|c|c|c|}
\hline Month & $\begin{array}{c}\text { Expected Energy (Tracker } \\
\text { Controlled) }(\mathrm{kWh})\end{array}$ & $\begin{array}{c}\text { Actual Energy (Tracker } \\
\text { Controlled) }(\mathrm{kWh})\end{array}$ \\
\hline Jan & 240.2 & 251.96 \\
\hline Feb & 259.4 & 269.87 \\
\hline Mar & 292.9 & 289.69 \\
\hline Apr & 278.4 & 266.40 \\
\hline May & 296.5 & 287.25 \\
\hline Jun & 297.8 & 279.24 \\
\hline Jul & 269.3 & 253.89 \\
\hline Aug & 278.1 & 259.20 \\
\hline Sep & 286.7 & 269.95 \\
\hline Oct & 263.7 & 256.92 \\
\hline Nov & 242.9 & 232.40 \\
\hline Dec & 238.8 & 220.30 \\
\hline Total & 3244.70 & 3137.07 \\
\hline
\end{tabular}

The actual energy generation is less in both cases when compared with simulated results i-e $176.54 \mathrm{kWh}$ less as compared to expected simulation result in case of fixed angle SPS and $107.63 \mathrm{kWh}$ less in case of tracker controlled SPS. The reason of the difference is quite obvious i-e meteorological conditions keep changing every year and system losses cannot be estimate accurately during simulations. Furthermore, weather conditions, dust factor, grid stability conditions and system maintenance are also not the same [18]. Besides this, another vital difference was recorded which was the basic requirement of this study i-e the difference between the actual yield of both the systems. It was recorded that the actual yield of fixed angle SPS was 2917.46 kWh and that of tracker based SPS was 3137.07 $\mathrm{kWh}$. So, a difference of $220 \mathrm{kWh}$ was observed which means tracker controlled SPS generated $220 \mathrm{kWh}$ more energy than fixed angle SPS. Summarizing the results, almost 7\% increase in energy generation was seen when a fixed angle SPS was replaced with a single axis tracker controlled SPS. Furthermore, this gain in energy yield was taken into account for cost and cash flow analysis.

\section{Cash Flow \& Cost Analysis}

Mathematical and financial techniques are adopted for cash flow analysis. Each system's BoQ is analyzed and compared with the energy saving cost to conclude the outcomes of this study.

\subsection{Cost of Fixed Angle SPS}

The total cost of fixed angle SPS is enlisted in Table 5 in the form of BoQ (Bill of quantity)

Table 5. BoQ for fixed angle SPS $2.0 \mathrm{kWp}$ with fixed angle grid connected system

\begin{tabular}{|c|c|c|c|c|}
\hline Sr. No & Product Description & Qty & $\begin{array}{c}\text { Per Unit } \\
\text { (PKR) }\end{array}$ & $\begin{array}{c}\text { Total } \\
\text { (PKR) }\end{array}$ \\
\hline 1 & $\begin{array}{c}\text { Inverter SMA 2 kW Sunny Boy } \\
\text { 2000-HF-30 }\end{array}$ & 1 & 84240 & 84240 \\
\hline 2 & $\begin{array}{c}\text { PV Modules made by Q Cells } \\
(250 \text { Wp })\end{array}$ & 8 & 21250 & 170000 \\
\hline 3 & Mounting Structure & 8 & 3500 & 28000 \\
\hline 4 & Cabling \& Conduits & 1 & 5500 & 5500 \\
\hline 5 & Civil Works & 1 & 3000 & 3000 \\
\hline 6 & $\begin{array}{c}\text { Balance of system, breakers, } \\
\text { nuts and bolts }\end{array}$ & 1 & 2500 & 2500 \\
\hline 7 & Installation \& Labour & 1 & 5500 & 5500 \\
\hline & Total Solution Price & \multicolumn{3}{|c|}{298740} \\
\hline
\end{tabular}

$100 \mathrm{PKR}=1 \mathrm{US} \$$

\subsection{Cost of Tracker Controlled SPS}

Similarly, the cost of tracker controlled PV system is mentioned in Table 6. This cost is little higher as it includes the expense of tracker control system.

\subsection{Cash Flow Analysis}

Cash flow analysis explains the payback period of the tracker control system and its profit in the coming years. Various factors are considered during cash flow study such as production degradation, energy price inflation and maintenance. The detailed cash flow analysis is shown in Table 7. 
Table 6. BoQ for single axis tracker controlled SPS $2.0 \mathrm{kWp}$ with single axis grid connected System

\begin{tabular}{|c|c|c|c|c|}
\hline Sr. No & Product Description & Qty. & Per Unit (PKR) & Total (PKR) \\
\hline 1 & Inverter SMA 2 kW Sunny Boy 2000-HF-30 & 1 & 84240 & 84240 \\
\hline 2 & PV Modules made by Q Cells ( $250 \mathrm{Wp}$ ) & 8 & 21250 & 170000 \\
\hline 3 & Mounting Structure & 1 & 35000 & 35000 \\
\hline 4 & Actuator and Control Circuit & 1 & 9750 & 9750 \\
\hline 5 & Cabling \& Conduits & 1 & 5500 & 5500 \\
\hline 6 & Civil Works & 1 & 10000 & 10000 \\
\hline 7 & Balance of system, breakers, nuts and bolts & 1 & 2500 & 2500 \\
\hline 8 & Installation \& Labour & 1 & 7500 & 7500 \\
\hline \multicolumn{3}{|c|}{ Total Solution Price } & \multicolumn{2}{|c|}{324490} \\
\hline
\end{tabular}

$100 \mathrm{PKR}=1 \mathrm{US} \$$

Table 7. Cash flow analysis \& payback estimation

\begin{tabular}{|c|c|c|c|c|c|}
\hline \multicolumn{2}{|c|}{ Electricity Production (kWh per Year) } & 220 & \multicolumn{2}{|c|}{ Electricity Price inflation per annum } & $5.0 \%$ \\
\hline \multicolumn{2}{|c|}{ Production Degradation per year } & $1.0 \%$ & \multicolumn{2}{|c|}{ Cost of installation } & PKR25750 \\
\hline \multicolumn{2}{|c|}{ Electricity Price } & 14.0 & \multicolumn{2}{|c|}{ Maintenance } & $0.1 \%$ \\
\hline Sr. & Year & $\mathrm{kWh}$ & Price/kWh (PKR) & Savings (PKR) & Total (PKR) \\
\hline 1 & 2014 & 220 & 14.00 & 3080 & -22670 \\
\hline 2 & 2015 & 218 & 14.70 & 3202 & -19468 \\
\hline 3 & 2016 & 216 & 15.44 & 3328 & -16140 \\
\hline 4 & 2017 & 213 & 16.21 & 3460 & -12681 \\
\hline 5 & 2018 & 211 & 17.02 & 3596 & -9084 \\
\hline 6 & 2019 & 209 & 17.87 & 3738 & -5346 \\
\hline 7 & 2020 & 207 & 18.76 & 3886 & -1460 \\
\hline 8 & 2021 & 205 & 19.70 & 4039 & 2579 \\
\hline 9 & 2022 & 203 & 20.68 & 4199 & 6778 \\
\hline 10 & 2023 & 201 & 21.72 & 4365 & 11143 \\
\hline 11 & 2024 & 199 & 22.80 & 4537 & 15680 \\
\hline 12 & 2025 & 197 & 23.94 & 47177 & 20397 \\
\hline 13 & 2026 & 195 & 25.14 & 1903 & 25300 \\
\hline 14 & 2027 & 193 & 26.40 & 5096 & 30396 \\
\hline 15 & 2028 & 191 & 27.72 & 5298 & 35694 \\
\hline
\end{tabular}

$100 \mathrm{PKR}=1 \mathrm{US} \$$

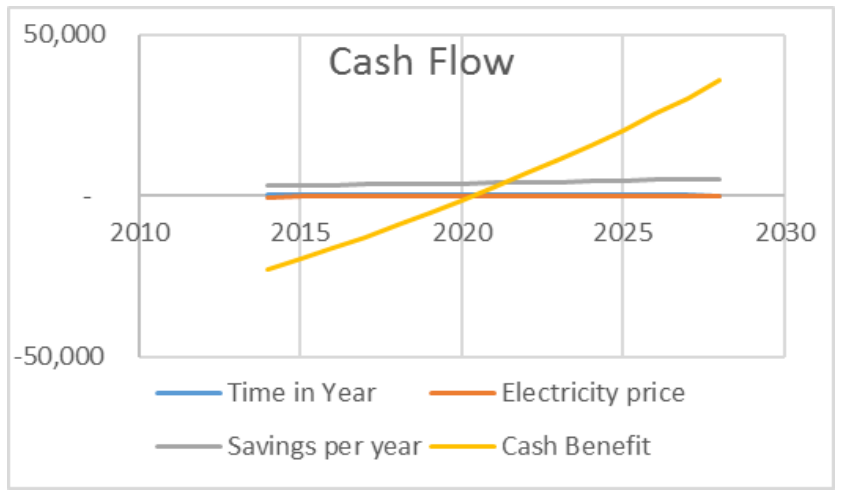

Figure 19. Cash Flow Graph

This graph in Fig. 19 explains that initial up rise of cash benefit in almost 7 years accounts for the payback whereas the profit is indicated after the line enters in positive region. This also provides baseline in calculating levelized cost of energy for tracker based projects. For renewable energy technologies the levelized cost of energy (LOCE) with minor operation and maintenance cost, provides the estimation of energy generation capital cost [19]. For a selected duration of period it provides the installation and plant operational cost for per $\mathrm{kWh}[20]$.

\section{Conclusions}

In this study there is $4 \%$ to $5 \%$ difference between simulated and practical energy generations, however actual 
results for are considered for further analysis and concluded that the energy generation of tracker controlled system was $7 \%$ greater than the fixed angle system however, the cost of tracker based system is high. The study also concludes that the additional cost of tracker will be recovered in about 7 years, or in other words LCOE of the tracker based system will be lower than the fixed angle SPS after that period.

\section{Acknowledgements}

The author expresses deep gratitude to Dr. H Mughal and M/S ASL for providing helping hand in this study. I would like to thank all my team members and above all Dr. Waqar Mahmood "Director KICS, UET Lahore" for being so supportive during this work.

\section{REFERENCES}

[1] Krebs FC, Spanggaard H. Significant improvement of polymer solar cell stability. Chemistry of materials. 2005 Oct 18; 17(21):52357.

[2] Parida B, Iniyan S, Goic R. A review of solar photovoltaic technologies. Renewable and sustainable energy reviews. 2011 Apr 30; 15(3):1625-36.

[3] Ahmed T, Wahid A, Saad A, Paul S. 2015. Development of Smart Hybrid Charge Controller, Proceedings of 1 st Multi-Disciplinary Student Research Conference, Wah Cantt, Pakistan. 2015 Nov 14-15; 154.

[4] Mousazadeh H, Keyhani A, Javadi A, Mobli H, Abrinia K, Sharifi A. A review of principle and sun-tracking methods for maximizing solar systems output. Renewable and sustainable energy reviews. 2009 Oct 31; 13(8):1800-18.

[5] Ponniran A, Hashim A, Munir HA. A design of single axis sun tracking system. In Power Engineering and Optimization Conference (PEOCO), 2011 5th International 2011 Jun 6 (pp. 107-110). IEEE.

[6] Bingol O, Altintas A, Oner Y. Microcontroller based solar-tracking system and its implementation. Journal of Engineering Sciences. 2006 Jun; 12(2):243-8.

[7] Barsoum N. Implementation of a prototype for a traditional solar tracking system. In Computer Modeling and Simulation,
2009. EMS'09. Third UKSim European Symposium on 2009 Nov 25 (pp. 23-30). IEEE.

[8] Chin CS, Babu A, McBride W. Design, modeling and testing of a standalone single axis active solar tracker using MATLAB/Simulink. Renewable Energy. 2011 Nov 30; 36(11):3075-90.

[9] Abas MA, Kadir SA, Azim AK. Improved structure of solar tracker with microcontroller based control. In Advances in Computing, Control and Telecommunication Technologies (ACT), 2010 Second International Conference on 2010 Dec 2 (pp. 55-59). IEEE.

[10] Anusha K, Chandra S, Reddy M. Design and development of real time clock based efficient solar tracking system. International Journal of Engineering Research and Applications. 2013; 3(1):1219-23.

[11] Chin CS. Model-based simulation of an intelligent microprocessor-based standalone solar tracking system. In MATLAB-A Fundamental Tool for Scientific Computing and Engineering Applications-Volume 3 2012. InTech.

[12] Chang YC, Chen YC, inventors; Sunplus Mmedia Inc., assignee. Solar tracking and concentration device. United States patent US 8,324,547. 2012 Dec 4.

[13] Nayak SR, Pradhan CR. Solar tracking application. IOSR J. Eng. 2012; 2:1278-1281.

[14] Roth P, Georgiev A, Boudinov H. Design and construction of a system for sun-tracking. Renewable energy. 2004 Mar 31; 29(3): 393-402.

[15] Abdallah S, Nijmeh S. Two axes sun tracking system with PLC control. Energy conversion and management. 2004 Jul 31; 45(11):1931-9.

[16] www.accuweather.com/en/pk/haripur

[17] Khan MF, Ali RL. Automatic sun tracking system, All Pakistan Engineering Conference, Islamabad, Pakistan, 2005

[18] Braun JE, Mitchell JC. Solar geometry for fixed and tracking surfaces. Solar Energy. 1983 Jan 1; 31(5):439-44.

[19] Narkhede MS, Chatterji S, and Smarajit G. Optimal dispatch of Renewable Energy Sources in smart grid pertinent to virtual power plant, 2013 International Conference on Green Computing Communication and Conservation of Energy (ICGCE), 2013.

[20] Branker K, Pathak MJ, Pearce JM. A review of solar photovoltaic levelized cost of electricity. Renewable and Sustainable Energy Reviews. 2011 Dec 31; 15(9):4470-82. 